\title{
Partial Response of Multiple Myeloma or Plasma Cell Leukemia
}

\author{
National Cancer Institute
}

\section{Source}

National Cancer Institute. Partial Response of Multiple Myeloma or Plasma Cell

Leukemia. NCI Thesaurus. Code C70641.

Partial response of multiple myeloma or plasma cell leukemia is characterized by a $50 \%$ or greater reduction in serum M-protein, and reduction in 24-hour urinary M-protein by $90 \%$ or more or to less than $200 \mathrm{mg} / 24$ hours. If the serum and urine $\mathrm{M}$-protein are unmeasurable (i.e., do not meet any of the following criteria: 1. serum M-protein at least $1 \mathrm{~g} / \mathrm{dL} ; 2$. urine $\mathrm{M}$-protein at least $200 \mathrm{mg} / 24$ hours; a 50\% or more decrease in the difference between involved and uninvolved free light chain levels is required in place of the M-protein criteria (provided the serum free light chain assay shows involved level at least $10 \mathrm{mg} / \mathrm{dL}$ and the serum free light chain is abnormal). If serum and urine $\mathrm{M}$-protein are unmeasurable, and serum free light assay is also unmeasurable, a 50\% or more reduction in plasma cells is required in place of M-protein, provided the baseline bone marrow plasma cell percentage was 30\% or more. In addition to the above listed criteria, a $50 \%$ or more reduction in the size of soft tissue plasmacytomas is also required, if present at baseline. Partial response requires two consecutive assessments made at any time before the institution of any new therapy, and no known evidence of progressive or new bone lesions if radiographic studies were performed; radiographic studies are not required to satisfy partial response requirements. 